\title{
Izaak Gotfryd Goedtke (1691-1765). Z badań nad studiami uniwersyteckimi i karierami prawników doby oświecenia ${ }^{1}$
}

W wydanej w 1724 roku Historii miasta Chojnic, Izaak Gotfryd Goedtke zamieścił dodatek pt. ,[...] o niektórych uczonych ludziach, którzy urodzili się w Chojnicach" (Anhang, von einigen gelahrten Leuten, so in Conitz gebohren") ${ }^{2}$. Zawiera on krótki opis sylwetek kilkunastu osób, które jego zdaniem szczególnie zasłużyły się dla rodzinnego miasta, zdobywając rozgłos i dochodząc niekiedy do najwyższych godności miejskich oraz akademickich. Dziś, podejmując próbę podobnej syntezy, nie sposób nie zaliczyć do tego grona właśnie Goedtkego. Był on wszak człowiekiem o wszechstronnych zainteresowaniach i zdolnościach - prawnikiem, historykiem i w końcu urzędnikiem (m.in. notariuszem, rajcą, burmistrzem), który większą część życia poświęcił Chojnicom oraz ich dziejom, wyróżniając się na tle innych mieszczan mniejszych miast Prus Królewskich. Zdawał już sobie z tego sprawę pochodzący z Chojnic, XVIII-wieczny rektor Uniwersytetu w Wittenberdze Johann Daniel Tietz (1729-1796). We wzorowanym na wspomnianej publikacji Goedtkego dziele „Informacja o uczonych pochodzących z miasta Chojnice”, obok innych, znamienitych postaci, zamieścił jego obszerny życiorys, opracowany na podstawie wspomnień sędziwego już wówczas Izaaka Gotfryda ${ }^{3}$.

Osoba Goedtkego jest dobrze znana nie tylko niemieckiej, ale także polskiej (przede wszystkim pomorskiej) historiografii. Jego obszerny biogram

${ }^{1}$ Artykuł powstał w związku z projektem Sukcesja spadkowa w miejszych miastach Prus Królewskich w II pot. XVII i XVIII w. (województwo pomorskie), finansowanym ze środków Narodowego Centrum Nauki, przyznanych na podstawie decyzji numer DEC-2013/11/N/HS3/04583.

2 I.G. Goedtke, Geschichte der Stadt Conitz/Historia miasta Chojnic, wyd. L. Stoltman, Chojnice 1998, s. 52 i n.

3 J.D. Titius, Nachricht von den Gelehrten welche von der Stadt Konitz des Polnischen Preussens herstammen, Leipzig 1763, s. 55-64. 
opublikował w „Słowniku biograficznym Pomorza Nadwiślańskiego” Stanisław Gierszewski ${ }^{4}$. Istotne rozwinięcie tych ustaleń zawierają prace Leona Stoltmanna, który przedstawił najważniejsze fakty z życia burmistrza oraz przybliżył jego pisarską spuściznę (Historia miasta Chojnic) ${ }^{5}$ oraz Adama Szwedy, który opublikował tłumaczenie Kościelnej historii Chojnic ${ }^{6}$. Pogłębione kwerendy źródłowe, zwłaszcza w Archiwum Państwowym w Bydgoszczy (w zespole akt miejskich Chojnic ${ }^{7}$ ), pokazują jednak, że obraz Goedtkego wciąż nie jest pełny i możemy rozwinąć go o wiele nowych, a jednocześnie niezwykle ciekawych kwestii. Warto zatem prześledzić losy jego życia, szczególnie w kontekście badań nad studiami uniwersyteckimi protestanckiej młodzieży z pruskich miasteczek, które nie znalazły dotychczas szerszego zainteresowania w historiografii ${ }^{8}$, jak i późniejszych losów pochodzących z nich absolwentów.

Przypomnijmy. Korzenie rodu Goedtke sięgają dolnosaksońskiego Brevensen, gdzie pradziadek Izaaka, Paul (1578-1665) pełnił funkcję burmistrza ${ }^{9}$. Jego syn Baltazar (Gotke), student teologii na Uniwersytecie w Wittenberdze oraz na Albertynie, przeniósł się do Prus Brandenburskich, osiadając w pobliżu Królewca, w miejscowości Poerschken (Swietloje), w której został pastorem. Tam urodził się ojciec burmistrza, Christian (1654-1705). Tak jak Baltazar, po studiach stanął na czele gminy ewangelickiej, najpierw w Żuławkach w starostwie niedźwiedzieckim, a od 1681 r. w Chojnicach. Od tego momentu ród Goedtków złączył swoje losy z tym miastem, wpisując się szybko w elitę jego mieszkańców. Christian był żonaty dwukrotnie. Jego pierwszą żoną była pochodząca z Gdańska Konstancja Cratoppia ${ }^{10}$. Z tego związku urodził się Konstanty, późniejszy kaznodzieja w Szawałdzie na Żuławach Malborskich (zm. 1742). Po jej śmierci pastor ożenił się z córką chojnickiego burmistrza - Elżbietą z d. Wilckin. Z tego małżeństwa pochodził urodzony 12 grudnia 1691 r. Izaak Gotfryd Goedtke.

Edukację rozpoczął w rodzinnym mieście, w tamtejszej szkole miejskiej. W tym czasie w Chojnicach funkcjonowały cztery szkoły: trzyklasowa ewan-

${ }^{4}$ S. Gierszewski, Goedtke Izaak Gotfryd (1691-1765), w: Stownik biograficzny Pomorza Nadwiślańskiego, t. 2, G-K, red. Z. Nowak, Gdańsk 1994, s. 74-75. Zob. też Z. Stomski, Pamięci godni. Chojnicki stownik biograficzny 1275-1980, Bydgoszcz 1986, s. 24; F. Pabich, Mały leksykon Chojnicki, Chojnice 1987, s. 29; K. Ostrowski, Goedtke Izaak Gotfryd, w: Bedeker chojnicki. A-Ż, Chojnice 2009, s. 126.

${ }^{5}$ L. Stoltman, Izaak Gotfryd Goedtke i jego przodkowie (1578-1765). Przyczynek do badań genealogicznych, „Zeszyty Chojnickie” [dalej cyt. ZCH], nr 22, 2007, s. 11-18; I.G. Goedtke, Geschichte der Stadt Conitz.

${ }^{6}$ A. Szweda, Izaaka Goedtkego Kościelna Historia Chojnic, ZCH, nr 18, 2003, s. 60-77.

7 Archiwum Państwowe w Bydgoszczy [dalej cyt. APB], sygn. 1675.

${ }^{8}$ M. Pawlak, Studia uniwersyteckie młodzieży z Prus Królewskich w XVI-XVIII w., Toruń 1988, passim.

${ }_{9}$ L. Stoltman, Izaak Gotfryd Goedtke, s. 11-42.

${ }^{10}$ A. Szweda, Izaaka Goedtkego Kościelna Historia Chojnic, s. 74. 
gelicka, pełniące funkcje szkoły średniej kolegium jezuickie oraz dwie inne, będące skądinąd przedszkolami, których uczniowie uczęszczali następnie do szkoły ewangelickiej ${ }^{11}$. $Z$ nich to kolegium miało wyjątkowo dobrą renomę. Świadczy o tym fakt, że pobierały tam nauki dzieci pruskiej szlachty, w tym członkowie bogatszych rodów. W mieście nie było natomiast szkoły wyższej. Z konieczności więc dalsza nauka tamtejszej młodzieży odbywała się poza Chojnicami. W 1705 r., wzorem innych, dobrze sytuowanych mieszczan Goedtke zaczął uczęszczać do Gimnazjum Akademickiego w Toruniu. Przyjęto go do najwyższej klasy - prymy (prima), co - jak słusznie zauważył L. Stoltman - spowodowało najprawdopodobniej, że we wpisie immatrykulacyjnym, zmieniono jego rzeczywisty wiek z 14 na 16 lat ${ }^{12}$. Nauka w cenionym ówcześnie ośrodku trwała krótko, do marca $1706 \mathrm{r}$. Wtedy to młody chojniczanin przeniósł się do Gdańska, by tam wpisać się w poczet uczniów miejscowego Gimnazjum. Tu spędził trzy kolejne lata pod okiem wybitnych nauczycieli, wśród których wyjątkowo cenił Jana Sartoriusa (język łaciński), Pawła Patera (geografia) czy długoletniego kierownika Katedry Historii i Prawa Samuela Fryderyka Willenberga (prawo naturalne, cywilne i kanoniczne). Na kilka miesięcy, od sierpnia 1709 do marca 1710 r., powrócił jednak do Chojnic ${ }^{13}$. Nic dziwnego, jako że z uwagi na szalejącą w Gdańsku zarazę, która ostatecznie wśród ponad 24000 ofiar (1/3 mieszkańców) zabrała 19 uczniów Ateneum i jednego z profesorów (Gabriela Groddecka [1699-1709], bezpieczniejszym wydawało mu się rodzinne miasteczko aniżeli zadżumiona metropolia nad Motławą ${ }^{14}$, zaś w sierpniu odwołano w Gimnazjum zajęcia, które zostały wznowione dopiero $\mathrm{w}$ grudniu ${ }^{15}$. Wyjazd nastąpił podczas kulminacji choroby przypadającej na wrzesień roku 1709 , kiedy to umierało nawet 1500 osób tygodniowo ${ }^{16}$.

W obu gimnazjach prawo stało na odpowiednio wysokim poziomie. Dawały one bowiem nie tylko wyższe wykształcenie, ale kształciły również osoby, które w przyszłości miały zasilić publiczne urzędy, w tym najważniejsze stanowiska w magistracie i na dworze królewskim. Stąd tak duży nacisk kładziono na gruntowną edukację $\mathrm{w}$ różnych gałęziach prawa. Zachowane programy przypadające na czas kierowania Katedrą Historii i Prawa przez Samuela Willenberga (1701-1748), a więc też częściowo okres edukacji Goedtkego w Gdańsku, pokazują, że w prymie wykładano w tym czasie prawo i historię

11 J. Rydzkowski, Chojnice w polowie XVIII w., ZCH, nr 1, 1964, s. 26-27.

12 L. Stoltman, Izaak Gotfryd Goedtke, s. 19.

13 J.D. Titius, Nachricht von den Gelehrten, s. 56.

14 Nie oznacza to, że Chojnice były wolne od zarazy. Plaga dawała tam o sobie znać jeszcze do końca 1711 r. Zob. A. Szweda, Izaaka Goedtkego Kościelna Historia Chojnic, s. 75.

15 E. Kizik, Gdańsk i Elblag w czasach zarazy z 1709-1710 roku, w: Dżuma, ospa, cholera. $W$ trzechsetna rocznice epidemii w Gdańsku i na ziemiach Rzeczypospolitej w latach 1708-1711, red. E. Kizika, Gdańsk 2012, s. 109.

${ }^{16}$ Ibidem, s. 104. 
cztery godziny $\mathrm{w}$ tygodniu, $\mathrm{w}$ sekundzie dwie ${ }^{17}$. Do tego dochodziły liczne wykłady prywatne. Skupiano się na prawie cywilnym (procesowym), rzymskim, natury, narodów oraz morskim, bazując w dużej mierze na wydanych przez tamtejszych profesorów kompendiach i podręcznikach ${ }^{18}$.

Edukację w Gdańsku Goedtke zakończył w 1710 r. Następnie, po rocznym pobycie u wuja w Kwidzynie (sierpień 1710-czerwiec 1711), postanowił kształcić się dalej i wstąpił na Uniwersytet w Królewcu ${ }^{19}$. Wybór tej właśnie szkoły wyższej nie był wcale przypadkiem. W Królewcu studiował bowiem już jego dziadek (od 1637 r.), ojciec (od 1678 r.) oraz przyrodni brat Constantin (od r. 1704) ${ }^{20}$. Był to również obok Lipska i Wittenbergi jeden z naturalnych kierunków dla pragnącej kontynuować naukę ewangelickiej młodzieży z Prus Królewskich (w tym także szlachty), gdyż mimo starań ani w Gdańsku, ani w Toruniu czy Elblągu, nie udało się powołać pełnoprawnego uniwersytetu $^{21}$. Do Królewca było zatem najbliżej, a i zapewne także relatywnie niskie w porównaniu do miast Europy Zachodniej koszty utrzymania nie pozostawały bez znaczenia. Z samych tylko Chojnic w latach 1544-1829 r. studiowało na Albertynie co najmniej 41 mieszczan, z których część powróciła następnie w rodzinne strony, rozpoczynając karierę urzędnicząą ${ }^{22}$ Jeżeli zaś chodzi o ogólną liczbę studentów z mniejszych miast pruskich na różnych, europejskich uniwersytetach do roku 1772, wczesnonowożytne Chojnice, z co najmniej 107 studentami, ustępowały tylko Malborkowi (598) i mieszkańcom Grudziądza $(150)^{23}$.

17 T. Maciejewski, Prawo i prawnicy w Gdańskim Gimnazjum Akademickim (XVII-XVIII wiek), w: Gdańskie Gimnazjum Akademickie. Szkice z dziejów, pod red. E. Kotarskiego, t. I, Gdańsk 2008, s. 366-369.

18 Tym niemniej ostateczny kształt programu zależał od osoby kierującej katedrą, więc wraz ze zmianą na tym stanowisku zmieniał się także zakres godzinowy poszczególnych przedmiotów oraz nacisk na określone materie.

19 L. Stoltman, Izaak Gotfryd Goedtke, s. 21.

20 Zob. Die Matrikel der Albertus-Universität zu Königsberg i. Pr. 1544-1829 (Personenregister und Heimatsverzeichnis), red. G. Erler, t. 3, Leipzig 1917, s. 136.

${ }^{21}$ L. Mokrzecki, Szkolnictwo gdańskie na tle szkolnictwa Rzeczypospolitej w okresie przedrozbiorowym, w: Z dziejów polskiej kultury i oświaty od średniowiecza do początków XX wieku, red. K. Jakubiak, T. Maliszewski, Kraków 2010, s. 21 i n.; M. Dzięcielski, Kultura polityczna i drogi awansu szlachty kaszubskiej. Studium nad elitami ziemi lęborskiej w XVI-XVIII wieku, Gdańsk 2010, s. 136-137, 146 i n. Wykaz ważniejszej literatury polskiej i niemieckiej dotyczący różnych aspektów funkcjonowania Albertyny zob. J. Jasiński, Historia Królewca, Olsztyn 1994, s. 279-280 .

${ }^{22}$ Die Matrikel der Albertus-Universität zu Königsberg, s. 594. Pewne uwagi krytyczne co do kompletności spisu: Die Matrikel der Albertus-Universität zu Königsberg (rec. P. Czaplewski), „Zapiski Towarzystwa Naukowego w Toruniu”, t. IV, 1917, nr 2, s. 51-55.

${ }^{23}$ M. Pawlak, Studia uniwersyteckie młodzieży z Prus Królewskich (Tabela 1. Pochodzenie społeczne studentów z Prus Królewskich w latach 1501-1772). W tym czasie Uniwersytet w Królewcu posiadał cztery fakultety - filozofii, teologii, prawa i medycyny. Wzorem ojca i dziadka Izaak początkowo planował zostać pastorem. Jako student miał tam styczność m.in. z profesorem logiki i metafizyki Paulem Rabe, metafizykiem Johannem Samuelem Oelmannem, rozpoczynają- 
Prawie dwu i pół roczne, niedokończone studia na Albertynie zakończyły się w listopadzie $1713 \mathrm{r}$. Stamtąd późniejszy burmistrz wrócił do Chojnic jak się okazało - nie na długo, gdyż postanowił kontynuować naukę na Uniwersytecie w Lipsku, gdzie pod naciskiem opłacającego jego studia dziad$\mathrm{ka}^{24}$ wstąpił na prawo ${ }^{25}$. Tam kształcił się pod okiem m.in. profesora prawa państwowego i międzynarodowego Karla Otta Rechenberga i historiografa królewskiego Johanna Burharda Mencke. Niedługo jednak zagrzał miejsce w tym mieście. W kwietniu 1714 r. przeniósł się do nieodległej i równie popularnej wśród pruskich studentów Wittenbergi. Nie wpisując się w poczet studentów, uczęszczał na prywatne i publiczne wykłady młodego prawnika Gebharda Bastinellera czy historyka Johanna Wilhelma Bergera.

$\mathrm{Z}$ powodów rodzinnych, z marzącej mu się kariery naukowej był zmuszony zrezygnować. Ostatecznie bowiem, w czerwcu 1715 r., na wyraźną prośbę owdowiałej już wówczas babki, powrócił do Chojnic i mimo możliwości angażu w Królewcu, w mieście rodzinnym pozostał.

Z prawem miał jednak styczność do końca życia. Szybko podjął pracę w magistracie, bowiem jeszcze na etapie przygotowań do wyjazdu do Królewca dostał ofertę posady miejscowego notariusza ${ }^{26}$, po zwolnieniu tego urzędu przez Johanna Vergina ${ }^{27}$. Faktem było, że w mniejszych miastach obsadzenie tej funkcji osobą z odpowiednimi kwalifikacjami stanowiło nieraz duży problem. Stąd taka propozycja nie dziwi, tym bardziej, że w końcu młody

cym dopiero karierę naukową przyrodnikiem Christianem Fischerem czy zwolennikiem pietyzmu Heinrichem Lysiusem, z którym prowadził teologiczne dysputy.

${ }^{24}$ Objął on nad nim pieczę po śmierci ojca, zmarłego podczas zarazy przywleczonej przez wojska szwedzkie w 1705 r. Zob. A. Szweda, Izaaka Goedtkego Kościelna Historia Chojnic, s. 74.

25 Jak sam podawał, studiowali tam także inni chojniczanie, m.in. Marcin Fuhrmannus, Burchard Harbartus, Franciszek Gericcius, Kaspar Schumannus, Krystian Hoppius czy Krzysztof Hoppius (formy nazwisk podaję za autorem), I.G. Goedtke, Geschichte der Stadt Conitz, s. 52-58.

${ }^{26}$ O notariuszach informowała księga przyjęć do prawa miejskiego: Henricus Leonard Mülichius (przyjęty w 1659 r.), Christof Hoppius (przyjęty w 1664 r., profesor filozofii i języka hebrajskiego w Gimnazjum w Toruniu, rajca Chojnic, zm. 15 V 1678 r.), Daniel Bucholtz młodszy (przyjęty w 1672 r., ławnik, syn burmistrza), Peter Salomon (przyjęty w 1675 r., notariusz we Friedland, potem Chojnicach, rajca i burmistrz, pochodził ze Sławna (Schlawe) na Pomorzu), Johann Vergin (przyjęty w 1715 r., notariusz, następnie ławnik, rajca, scholarcha, burmistrz), Joannes Albertus Klewert (przyjęty w 1741 r., rajca, burmistrz, zmarł w 1768 r.), Christoph Biber (ławnik, zm. w 1760 r.), Heinrich Benjamin Ksepka (notariusz od 1760 r.), Bürgerbuch der Stadt Conitz 1550-1850, oprac. E. Kloss, Danzig 1927, s. 39, 41-42, 52, 57, 59, 63. O Hoppiusie pisał Goedtke, że ,[...] Tu w swoim ojczystym mieście [Chojnicach - P.K.] był początkowo notariuszem i rajcą, w roku 1670 ustąpił z notariatu w zamian za funkcję kamlarza. Wreszcie w roku 1672 został burmistrzem" (I.G.G., Historia miasta Chojnic, s. 57-59). Chojniczanin wspominał również że notariuszem był Joann Andreas Salomon. Urodzony w 16 XI 1675 r., prawo studiował w Królewcu. W 1698 wybrany na funkcję notariusza, późniejszy ławnik (od 1704 r.), rajca (od 1708 r.) i burmistrz. Zrezygnował z urzędu i w Halle zdobył tytuł doktora medycyny. Medyk w Gdańsku (ibidem, s. 64-65).

${ }^{27} \mathrm{Na}$ temat pisarzy w małych miastach Prus Królewskich na przykładzie Nowego nad Wisłą zob. P. Kitowski, Notarius civitatis w kancelarii miejskiej Nowego nad Wisła w XVIII wieku, „Studia z Dziejów Państwa i Prawa Polskiego", t. XVII, 2014, s. 61-73. 
chojniczanin spędził kilka lat na zagranicznych uniwersytetach, kształcąc się w kierunku pożądanym dla wykonywania obowiązków pisarskich. Rzeczywiście, w lipcu 1716 r. objął ten urząd, który z sukcesami pełnił przez kolejne 20 lat do czerwca $1736 \mathrm{r}$.

W roku 1735 wybrano go do rady. Zrezygnował jednak z tej propozycji, przyjmując ją dopiero podczas kolejnej kiery (1736). Wtedy też złożył funkcję notariusza. W tym samym roku powołano go jako asesora (1736-1738) chojnickiego sądu opiekuńczego, którego przewodniczącym został po raz pierwszy 6 lat później w 1744 r., a następnie w latach 1751-1752, i 1757$-1758^{28}$. Ponadto w $1738 \mathrm{r}$. został podskarbim miejskim oraz scholarchą, rok później otrzymał tytuł Radcy Dworu Królewskiego, zaś w lutym 1742 r. obrano go burmistrzem-prezydentem ${ }^{29}$. W wieku 51 lat osiągnął więc wszystkie szczeble magistratu, pełniąc najważniejsze urzędy w mieście.

Zaczęło mu się wieść także w życiu rodzinnym. Mimo stosunkowo poważnego wieku (45 lat), pojął za żonę wdowę po bogatym rajcy Chojnic Eliaszu Senfie, Marię Elżbietę (z d. Benewitz, 28 sierpnia 1736 r. ${ }^{30}$, zm. w 1770 r.). Chociaż nie doczekali się potomstwa, to z poprzedniego małżeństwa Maria posiadała aż ośmioro dzieci, które wspólnie z drugim mężem wychowała. Jeden z jej synów, a więc pasierb Goedtkego, tak jak ojczym studiował później prawo w Lipsku, po którego ukończeniu osiadł na stałe w Gdańsku. Najstarszy z pasierbów Ezajasz Senf został farbiarzem. Podobnie jak Izaak zasiadał w sądzie opiekuńczym najpierw jako asesor (1761-1768), a w końcu także jako przewodniczący $(1770)^{31}$.

Co ważne, burmistrz nie zrezygnował również z zainteresowań naukowych. Wśród jego licznych druków wyróżnia się wspomniana Historia Miasta Chojnic oraz historia kościołów małych miast ${ }^{32}$. Oparł je na łatwo dostępnych z racji pracy notariusza dokumentach oraz dość pokaźnej bibliotece, jaką kompletował przez całe życie. Było w niej ponoć ponad 300 woluminów, które w trakcie jednego z pożarów, który strawił niemal całe miasto $(1742)^{33}$, uległy w dużym stopniu zniszczeniu. Jego inwentarz pośmiertny z roku 1765 r. zawierał już tylko 38 pozycji, głównie historycznych, prawniczych

28 APB, sygn. 1675/53, s. 33-38 (Isaacus Godofredus Goedtke).

29 J.D. Titius, Nachricht von den Gelehrten, s. 59-60.

${ }^{30}$ L. Stoltman, Izaak Gotfryd Goedtke, s. 33. Miesiąc wcześniej, 28 lipca 1736 r. małżonkowie zawarli kilkupunktową umowę przedmałżeńską, APB, 196/147, s. 791-793. Podczas podpisania intercyzy Elżbiecie towarzyszył kasztelan chełmiński Jan Michał Grabowski (APB, 186/147, s. 793).

${ }^{31}$ Był obecny podczas sporządzenia inwentarza pośmiertnego Goedtkego. Czynności asystował również Christoph Hennig Nobershausen (Naberhausen), APB, 196/147, s. 736.

32 J.D. Titius, Nachricht von den Gelehrten, s. 62-63.

33 J. Rydzykowski, Chojnice w połowie XVIII wieku, s. 20; Bürgerbuch der Stadt Conitz 15501850, s. 54. 
i religijnych ${ }^{34}$. W kontekście bibliotek innych mieszczan mniejszych miast, owe kilkadziesiąt egzemplarzy stanowiło i tak sporą ilość, nie mówiąc o pierwotnym zasobie jego księgozbioru ${ }^{35}$.

Można zapytać, czy Goedtkemu pozostanie w Chojnicach opłaciło się, czy też jego skądinąd wymuszona decyzja nie okazała się być taką, której by po latach żałował. W sensie materialnym wiodło mu się całkiem dobrze. Według spisu mieszkańców z 1749 r. posiadał trzy domy (dwa z nich wynajmował), mielcuch z ogrodem, karczmę $\mathrm{z}$ gościńcem oraz dwa puste place na chojnickim Nowym Mieście ${ }^{36}$. Był to dość spory majątek, który nie przypadł po jego śmierci wyłącznie rodzinie. Być może z uwagi na wzmiankowany pożar z kwietnia 1742 r., w lipcu tegoż roku wraz z żoną sporządził testament. Wzorem innych znamienitych chojnickich patrycjuszy (np. M. Fuhrmanna) dokonał w nim zapisu ad pias causae w wysokości 1000 guldenów pruskich, z których to miano m.in. wspierać miejscową młodzież, uczącą się w gimnazjach oraz podejmującą studia wyższe na uniwersytetach ${ }^{37}$. Ustanowiono go na $6 \%$ prowizję, wypłacaną corocznie w listopadzie, $w$ dniu imienin fundatorów (13-14 listopad). W razie gdyby nie było w tym czasie studentów potrzebujących wsparcia, połowa prowizji przechodziła na rok kolejny.

23 lata po dokonaniu tego zapisu, 6 czerwca 1765 r. sędziwy i poważany przez mieszczan burmistrz zmarł.

${ }^{34}$ Były to przede wszystkim prace z zakresu prawa cywilnego oraz karnego, np.: rękopis niewymienionej z tytułu rewizji prawa chełmińskiego (Das Culmische Recht, niedatowany, można domniemywać, że chodziło o egzemplarz Rewizji Toruńskiej z 1594 r., którą później wydał drukiem Michael Hanow: Ius Culmense ex ultima revisione oder das vollständige Kulmische Recht, wyd. M.C. Hanow, Danzig 1745, 1767), Corpus Juris Canonici (G.P. Lancellotti, Wittenberg, 1650), Ius Canonicum (C. Ziegleri, Wittenberg, 1669), Praxis Rerum Criminalium (J. Damhouder, Antwerpen 1616), Tractatus Iuridicus de Inquisitionis Processu (J. Brunemann, Lipsiae 1732), Commentatio succincta ad Institutiones Iustiniani (J. Hoppii, Francofurti ad Odram 1712), Exercitationes ad Pandectas (J.J. Wissenbach, Franeker 1673), Commentarii in Institutiones (J. Schneidewin, Coloniae 1698), Discursus juris, in selectas ejus materias (S.F. Willenberg, 1729) czy Syntagma Iuris Civilis (G.A. Struve, Jena 1672). Historii poświęcone były Historia Lithuaniae (W. Kojalowicz, cz. II, Antwerpen 1669?), Pommersche Kirchen-Chronik (B. Cramer, Stettin 1628), Historia orbis terrarum, geographica et civilis (J.Ch. Bekmann, Francofurti ad Odram 1692), Polnische Chronik oder historische Nachricht von dem Leben und Thaten aller Herzoge und Könige in Polen (S.F. Lauterbach, Leipzig 1727), Obsidio Clari Montis Czestochoviensis (S. Kobierzycki, Dantisci 1659). APB, 1675/147, s. 727-736.

35 Problem omawiam w P. Kitowski, Sukcesja spadkowa w mniejszych miastach Prus Królewskich w II pot. XVII i w XVIII w. (województwo pomorskie). Studium historyczno prawne, Wydział Prawa i Administracji Uniwersytetu Gdańskiego, Gdańsk 2014, s. 252-255, maszynopis pracy doktorskiej napisanej pod kierunkiem prof. zw. dr hab. Edmunda Kizika.

36 Według tego samego spisu np. rajca Michael Kuppisch był właścicielem domu na Starym Mieście i domku na przedmieściu. Podobnie wyglądał majątek innego członka rady, Georga Lesse. L. Stoltmann, Izaak Gotfryd Goedtke, s. 35; Dzieje Chojnic, s. 142.

${ }^{37}$ APB, sygn. 1675/151, s. 654-655. Wpis do ksiąg Chojnic z 27 maja 1771 r. Zapisu dokonano 17 lipca 1742 r. Zob. też M. Pawlak, Studia uniwersyteckie młodzieży z Prus Królewskich, s. 97-98. 
Reasumując, opisana droga edukacji i pracy zawodowej Izaaka Gotfryda Goedtke przypomina losy innych, bogatszych protestantów z pomorskich miasteczek. Po kształceniu podstawowym i średnim, które odbywali w rodzinnych miastach, kolejnym etapem był zwykle Gdańsk lub Toruń, gdzie przygotowywano ich do studiów uniwersyteckich. $Z$ wielu, głównie materialnych powodów na miejsce dalszej nauki wybierali przede wszystkim Królewiec. Albertyna była jednak często jedynie przystankiem przed właściwymi studiami, na którymś z niemieckich uniwersytetów, w Lipsku, Rostocku czy Wittenberdze. Po ich ukończeniu absolwenci mieli wiele dróg wyboru. Jedną z nich był powrót do miejsca urodzenia oraz kariera $\mathrm{w}$ magistracie. Jak wynika z analizy losów wybranych absolwentów studiów prawniczych, na taki krok decydowało się sporo osób. Szczególnie jeśli weźmiemy pod uwagę fakt, że nawet nieukończone studia dawały im przygotowanie do objęcia urzędu notariusza czy ławnika. Tym bardziej, że w warunkach mniejszych miast można było zauważyć problemy w obsadzeniu funkcji pisarza, a w skład sądu ławniczego wchodziły najczęściej osoby bez odpowiedniego przygotowania prawniczego - drobni kupcy oraz rzemieślnicy, których edukacja zakończyła się na poziomie podstawowym bądź średnim. Powrót, niejednokrotnie inicjowany przez miejscowe władze, gwarantował stabilizację życiową, stosunkowo łatwy zarobek, a z czasem awans na szczeblach magistratu. Tak też zrobił Goedtke i jak wynika z jego wspomnień, decyzji tej nie żałował.

\section{IZAAK GOTFRYD GOEDTKE (1691-1765). ON THE ACADEMIC STUDIES AND CAREER OF LAWYERS IN THE ENLIGHTENMENT PERIOD}

\section{Summary}

Relatively little is known about the education of the youth from small Polish towns in the Enlightenment period. Although a number of major studies have been devoted to university studies in the $16^{\text {th }}, 17^{\text {th }}$ and $18^{\text {th }}$ centuries, there are only few publications which addressed so called Civitates Terrarum Prusiae - little towns from Royal Prussia. This article sheds some light on the life of Isaac Gotfryd Goedtke, an $18^{\text {th }}$ century city mayor and historiographer of Chojnice (Konitz). Goedtke belonged to one of the most outstanding burghers who, after studies at German universities, returned to his hometown, only to begin a successful civil service career. 
IZAAK GOTFRYD GOEDTKE (1691-1765). DES RECHERCHES SUR LES ÉTUDES UNIVERSITAIRES ET LA CARRIÈRE DES JURISTES AU SIÈCLE DES LUMIÈRES

\section{Résumé}

Nous savons toujours relativement peu au sujet de l'éducation des jeunes polonais issus des villes plus petites au Siècle des Lumières. Et même si des études abordant les questions liées à la formation des étudiants par les universités entre les XVI ${ }^{\mathrm{e}}$ et $\mathrm{XVIII}{ }^{\mathrm{e}}$ siècles existent, il manque de recherches détaillées consacrées aux petites villes et au sort des anciens élèves originaires de ces centres-là. Le problème concerne également des soi-disant Civitates Terrarum Prusiae, les villes de moindre taille de la Prusse royale. Le présent article essaie donc de nous rapprocher la silhouette et le destin d'un habitant de Chojnice qui s'appelait Izaak Gotfryd Goedtke. C'est un homme qui fait partie des plus remarquables citadins, et pas seulement en Prusse. Or, après des études inachevées, il retourne dans sa ville natale pour commencer une carrière de fonctionnaire qui s'avère une vraie réussite. Goedtke a su très habilement lier son parcours professionnel et la réalisation de sa passion qui était l'histoire. Parvenu aux plus hautes fonctions, il devient l'auteur reconnu de l'histoire de la ville de Chojnice. Sa vie peut donc être considérée comme une contribution aux recherches sur la vie d'autres citadins et début d'un débat plus vaste qui leur aura été consacré. 